\title{
ESP Network Curriculum Design Based on Constructivism
}

\author{
Ming Wang ${ }^{1, a}$, Dachao Yuan ${ }^{2}$ \\ 1 School of Foreign Languages, Wuhan University of Technology, Wuhan, China \\ 2 Office of Science and Technology Development, Wuhan University of Technology, Wuhan, China
}

Keywords: ESP, Network Curriculum, Design.

\begin{abstract}
Computer and Internet technology have been widely applied in the elementary stage of English study in Chinese universities. However, how to exploit the advantages to promote ESP course teaching reform remains to be discussed. This paper aims at the major issues existing in ESP curriculum teaching and proposes a design combining ESP curriculum teaching principle and ESP curriculum teaching reform in order to efficiently utilize network technology and resource to develop ESP curriculum teaching.
\end{abstract}

\section{Introduction}

ESP is the abbreviation of English for Specific Purpose. Hailiday underlined the specific orientation of ESP. ESP is a type of English that relates to specific occupations, subjects or purposes. It has two significant features: one is the user who has specific application range, which means the user has to use English in his working field out of his job necessity; the second one is the special language content, namely the specialized content[3]. With the rapid development of international economic globalization, the intercommunication becomes more frequent between China and other countries. The Minister of Education and Finance on higher school undergraduate teaching quality and reform project proposed to improve undergraduates' English proficiency and the ability using English directly in scientific research, which definitely puts ESP teaching on the agenda[2]. China has been exploiting ESP teaching since the 1970'. ESP teaching was popular in colleges for a time, but depressed since the 1990'. The reason why this situation happened is there are plenty of problems in the ESP teaching processing of China colleges, such as lacking in qualified teachers, the construction of teaching material is not enough, the teaching method is seriously out of date, and the evaluation system is not perfect, etc. ESP multimedia network curriculum design is an advantageous attempt to overcome these issues. It's different from the past teaching pattern. It has the features of flexibility and openness no matter in the course construction, teacher ratio, learning resource, learning method or evaluating method, and it can satisfy different learning demands from different learners.

\section{Course Design Theory}

ESP curriculum design basing on network is mainly based on constructivism theory. Constructivism theory is an important branch of cognitive learning theory, stressing on cognitive subject's internal

a Corresponding author : 10611853@qq.com 
mental process. Learners are the main body of information processing. Network teaching creates a discovery learning environment and method for students. It has network functions such as a large amount of information, the strong interaction and multimedia information, which helps to improve students' enthusiasm of learning, strengthen students' confidence, dig up students' potential and develop students' ability of asking and solving questions as well as creativity. Besides, this way of learning benefits students to arrange their own learning contents and schedules accordingly. During the learning process, teachers and students take part in teaching activities equally. Teachers are regulators and guiders, but the whole activity proceeds under students' control. Students utilize information from Internet and coordinate with others. It gives full play to the students' leading function during the teaching activity.

Constructivism theory focuses on the design of learning environment. It concerns that learning has to be in substantial situation, for learning is a build process that relies on the assistance of interpersonal activities under specific situations. As a result, it comes up with four elements of learning environment, namely "environment, coordination, communication, meaning constructivism", among which environment is the most important component of learning process. Interactive network not only offers rich materials and necessary supports for learners, but also provides convenience for learners' cooperation and communication, reinforcing learners' assistance during learning process and consolidating interaction between teachers and students, thereby improving learners' cognitive competence and pragmatic competence[6].

\section{Course design principle}

ESP course is an important curriculum system, which makes sure various-leveled students be fully trained and improved in the aspect of English application ability, as well as an important component of network-based college English subsequent courses[1]. So, design of ESP course teaching pattern should doubtlessly base on its own feature, and be designed according to a certain principle.

\subsection{Clearing the learning target of ESP courses}

The development purpose of web-based ESP courses is to further improve students' autonomous learning ability, cultural quality and the use of English language practice ability. Without doubts, the initial principle of ESP course design is to follow the principle of student subjectivity and to give full play to the subjective initiative of students, dynamically combining humanity and Instrumentality[4]. Take the marketing English as an example. When the web course is proceeding, it emphasizes on what students should study to understand and handle vocabularies, syntaxes, and terms of marketing English. As a language course, the target of the course should be teaching English knowledge and technical about the marketing profession, rather than discussing in depth about systematic marketing professional knowledge.

\subsection{Design of courseware should be student-centered}

When many teachers make courseware, they still focus on themselves. They use multimedia teaching equipment instead of traditional chalks, but they just cram their students and try to control the whole learning process. The ESP curriculum sets up at senior stage of college. At that time, students already have enough knowledge to learn professional English. So, ESP network teaching is a dynamic process that teachers and students interact with each others with the assistance of multimedia teaching equipment. Students are able to express their ideas, opinions and propositions, and even to question humanity, technology and English evaluation of their own majors. 


\subsection{Choosing course content rationally}

As the important content of college English follow-up course, the design of ESP course is languagecentered, technique-centered and learning-centered. According to the features of network, we should develop ESP learning modules and courses to adapt to different students based on students' knowledge structures and demands. For instance, we should design business English, tourism English, technology English, medical English and etc. According to students' professions, employments and interests, and dividing above-mentioned classifications into the first level, second level and third level, to satisfy all levels of various kinds of students' learning demands.

\section{Curriculum design}

\subsection{Take fully use of the network curriculum}

We should change the role of teachers and establish a student-centered teaching environment. Recently, with the development of second language, people gradually realize it's the learner himself that decides the learning result, and they more and more emphasize learner-centered theory. We can give full play to the advantages of network and change the role of teachers, establishing a "learnercentered" ESP teaching environment[5]. Firstly, in the network environment, we should implement interaction with teachers and students with the help of computer network, by which teachers can teach collectively, and also communicate with students respectively through network teaching platform, teaching students in accordance of their aptitudes. Secondly, students can decide their own learning curve and learning content according to their language levels, interests and styles, so that giving full play to their subjective initiative. Also, students can consult with teachers with the help of network according to their own qualities, realizing the individualized learning. By this way, ESP course teachers can really fulfill their duties during teaching process, playing a role of organizers and guiders, establishing a student-centered beneficial teaching environment.

\subsection{Utilize the network resources, and enrich the teaching content}

(1)The development of the network can provide most ESP teachers with rich real teaching materials, in order to solve the problem of the ESP teachers' lack of information resources.

ESP teaching is an English teaching form included a lot of professional knowledge. According to the principles of ESP teaching, teachers, as the provider of the learning materials, should select the appropriate materials to adapt based on students' needs. As the major network language is English, many professional websites are advantageous material databases for ESP teachers. They can provide a lot of teaching materials to quickly update knowledge. There are various online journals to provide many free learning materials for teachers and students. ESP teachers, for instance, can choose professional articles which are suitable for students' levels to recommend students for reading. That can stimulate students' interest, help them to master reading skills and enlarge vocabulary, in order to understand the latest development of their majors. Students can also search all kinds of information related to the major online. They can analyze, select and utilize all the information. In this way, students can not only learn about the development of the major and the latest knowledge, but also learn authentic English unconsciously in the process of handling information. And they can use authentic language to achieve the purpose of the actual communication.

(2)Using the Internet to improve the ESP courses teaching of listening and speaking which is weak for most of the students.

ESP teaching in China almost don't conclude training of listening and speaking due to the reasons such as classes or teachers. However, students generally desire to strengthen the training of listening and speaking in the ESP courses, to improve their skills of listening and speaking. So they can achieve in the level of international communication. Internet can establish the language environment of sound, which creates good conditions for listening and speaking training of ESP teaching. At first, there are technical online resource sites of listening and speaking, in which there are interactive exercises and 
explanation. Some of them have audioscripts. All of these can help students' self-study. Secondly, online radio can be used to strengthen students' listening practice. Online radio on internet transfers signals by digital circuit. In that, the transmission effect is good and the content is latest. Such as financial reports of English news from VOA and $\mathrm{BBC}$ have great timeliness, which can stimulate students' enthusiasm and is suitable for students of economics to have listening and speaking training. Therefore, that guiding students to listen to the online radio is not only to improve the level of listening of students, but also help them to understand the development of latest world economic.

\subsection{Reform evaluation system and ensure the teaching effect}

According to ESP teaching targets, we can formulate scientific and reasonable evaluation and assessment system of ESP, which is the guarantee for ESP teaching. We can utilize the network to reconstruct the evaluation system of ESP, and focuses on students' actual language application ability. At first, we should establish a multidimensional network evaluation system, including the teachers' evaluation, learning partner evaluation and learners' self evaluation. We also can make use of database technology and network technology to monitor the whole process of ESP teaching, which can be the objective basis for the evaluation of teaching. Secondly, combining formative assessment and summative assessment, we can learn more about students' learning needs, learning progress, and problems, etc., through formative assessment, in order to timely adjust and improve teaching. Finally, we can make use of advanced network technology and means to reform the evaluation mode of ESP courses. Except traditional written test, we can set up computer-based spoken tests and put in research reports, etc. We can establish scientific evaluation system to overcome the blindness and randomness in the ESP teaching, and to guarantee the ESP curriculum teaching effects and make it on the track of specification development.

Therefore, ESP multimedia network course design involves four teaching steps, namely input $\rightarrow$ internalize $\rightarrow$ output $\rightarrow$ evaluation. The process of input is transforming others' experience into the brain. The process of internalized is to repeat process, imitate, practice obtained knowledge and experience to oneself knowledge. The process of output is to display internalization knowledge. Evaluation is the detection of the output effect. The implementation of the curriculum design can be divided into five interactive modes, as shown in Table 1.:

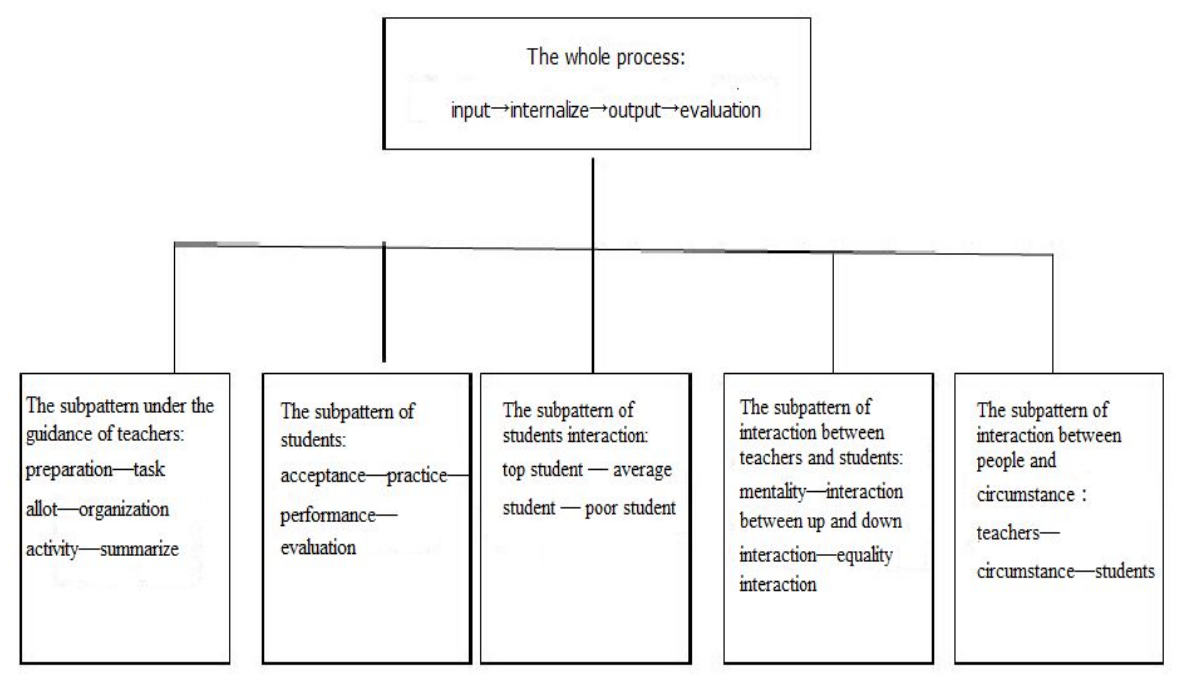

Figure 1. ESP Multimedia Network Course Design. 


\section{Conclusions}

Along with the future university English teaching reform, ESP teaching reform is beginning to receive more attention. We believe that the use of computer and network in ESP teaching will show incomparable advantages and great potentials. Therefore, the teachers engaged in ESP teaching should actively explore the effective ways to improve the teaching quality of ESO under the network environment, to cultivate interdisciplinary talents, and to adapt to the society and era development. Specialized English is the language of the specific context. It is more effective to learn in the real circumstance. The network environment provides a multidimensional approach and simulation training platform for language inputs. During the teaching of English for special purposes, we should effectively guide the students to change from general English to special English. Special English is a kind of cross-cultural communication. The language identification method to overcome the interference of the mother tongue is also very important. All in all, reform and integration of a variety of teaching methods is convenient for inputting, understanding, identifying, memorizing and outputting of language, to provide strategies and methods of implementation for development and utilization of network courses.

\section{Acknowledgements}

This paper is supported by the Project "On the Mode of the English Talents Cultivation Based on ESP Theory (20151h0139)".

\section{Reference}

1. Gao Yunfeng. The development and application of ESP English network courseware. University Education, 12(2014)

2. Gu zhizhong. The design research of the special English courses. Shanghai: Shanghai international studies university, 2010.

3. Jarvis, J. Two core skills for ESP teachers. The ESP Journal, 2(1983)

4. Liu Xin. The theory of influence of the network-based ESP teaching mode on learning autonomy. Foreign Language Research, 2(2013)

5. Mo Lili. The discussion of ESP professional inquiry learning mode based on the Internet. Journal of Ningbo university(education science edition), 5(2011)

6. Zhang Honglin. Network foreign language teaching theory and design (Shanghai foreign language education press, 2010) 